\title{
MADEIRA ISLAND - DESTINATION IMAGE AND TOURISTS LOYALTY
}

\author{
Luiz Pinto Machado ${ }^{\mathrm{a}}$, Carlos M. Santos ${ }^{\mathrm{b}}{ }^{*}$ and Manuela Sarmento ${ }^{\mathrm{c}}$ \\ ${ }^{a}$ School of Hospitality and Tourism, Madeira Island, Portugal. \\ ${ }^{\mathrm{b}}$ University of the Azores, Ponta Delgada, Azores, Portugal

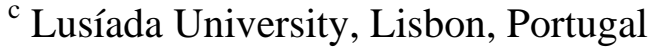 \\ *Corresponding author, e-mail: csantosort@gmail.com
}

\begin{abstract}
This study uses a Logit model to examine the probability of the image of the tourism destination Madeira, a Portuguese autonomous insular region, being strengthened after the tourists's visit to the destination. The results of the empirical study are based on a survey carried out to tourists during their visit to the island of Madeira, between March and July 2008. The model confirms that the probability of enhancing Madeira's tourism destination image after the visit is explained by several independent variables, gathered from the literature review. The findings of the study intend to call local authorities's attention to the importance of repeated tourists due to the impact that their enhanced image of Madeira may have on the economic sustainability of the destination and on the potential savings in promotion investment. This happens because the client's loyalty brings a high return of the destination's marketing investment. The conclusions can also help the decision makers of the tourism sector of the island of Madeira to better plan their destination marketing activities.
\end{abstract}

Keywords: Destination image, service quality, satisfaction, loyalty, sustainability

\section{Introduction}

The globalization of international tourism brings about important changes in terms of tourism marketing, the tourist's profile and technological aspects. The emergence of new destinations in the geography of international tourism has allowed a significant increase in supply over demand and, therefore, in the global competition among destinations.

The "shortening" of the distances also increases the number of new destinations competing with the traditional ones. Under those circumstances, the marketing of destinations has to be more aggressive and effective, since they are competing with a wider and qualified supply. Tourism marketing campaigns are becoming increasingly creative. The provision of new tourist destinations is immense and the competition between alternative destinations is based on a consistent and sustained tourism supply with high quality and a high performance, reflected in the diversity of tourism products, in a service of excellence, in competitive prices and, above all, in a good communication to the client. 
The archipelago of Madeira, comprising the islands of Madeira and Porto Santo, together with the regions of the Algarve and Lisbon are the main tourist destinations in Portugal.

Table 1 Tourism statistics for Portugal and Madeira for 2007

\begin{tabular}{|l|l|}
\hline Statistics & Figure \\
\hline Portugal & \\
\hline Number of Hotels & 2031 \\
\hline Overnights & 39736583 \\
\hline Number of beds & 264747 \\
\hline Bed occupancy rate & $43 \%$ \\
\hline Madeira & \multicolumn{2}{|l|}{} \\
\hline Number of Hotels & 187 \\
\hline Overnights & 5990015 \\
\hline Number of beds & 27297 \\
\hline Bed occupancy rate (\%) & $60.30 \%$ \\
\hline
\end{tabular}

Source: Madeira Statistical Bureau

In 2007, according to the official regional statistics bureau, Madeira hotels represented 9.2\% of the total number of hotels in Portugal, 15\% of total overnights and $10 \%$ of total beds (Table 1 ).

The island of Madeira, despite being one of the oldest tourist destinations in the world, does not escape the increased international competition. It has registered, especially in recent years, a negative, zero, or negligible growth in the number of international tourists, while the supply of tourist accommodation has grown well above demand.

Table 2 Estimated annual change in overnights in the main incoming markets

\begin{tabular}{|l|c|}
\hline Statistics & $\begin{array}{c}\text { Annual change } \\
\mathbf{( 2 0 0 8 / 2 0 0 7 )}\end{array}$ \\
\hline Number of Guest: & n.a. \\
\hline Residents in Portugal & n.a. \\
\hline Non residents in Portugal & n.a. \\
\hline Overnights: & $3.60 \%$ \\
\hline Residents in Portugal & $4.90 \%$ \\
\hline Non residents in Portugal & $-5.30 \%$ \\
\hline Number of operating lodging units & $1.60 \%$ \\
\hline Number of Beds & $2.70 \%$ \\
\hline Bed Occupancy Rate (\%) $* *$ & $+0.3 \%$ \\
\hline
\end{tabular}

Source: Madeira Statistical Bureau

n.a. - numbers not available 
As a matter of fact, as we can see in Table 2, between 2007 and 2008, the number of overnights of non residents in Portugal in the Madeira hotels has decreased $-5.3 \%$, while the number of hotel beds increased $2.7 \%$. Table 3 shows the recent changes in total revenues, room revenues and revpar in Madeira hotels. All three indicators decreased between January 2008 and January 2009.

Table 3 Income and RevPAR in Madeira hotels

\begin{tabular}{|l|c|c|c|}
\cline { 2 - 4 } \multicolumn{1}{c|}{} & January 2008 & January 2009 & Change \\
\hline Total Revenues (in thousand euros) & 19331 & 16498 & $-14.7 \%$ \\
\hline Room Revenues (in thousand euros) & 12109 & 10310 & $-14.9 \%$ \\
\hline RevpPAR (euros) & 29.4 & 24.11 & $-18 \%$ \\
\hline
\end{tabular}

Source: Madeira Statistical Bureau

Although prices are going down, the tourism accommodation maintains its high quality standards. Therefore, marketing plays an increasingly important role to attract an increasing number of tourists. All forms of advertising should be used to capture the attention of even the most distracted potential tourists. However, dispersed occasional publicity actions and generic advertising are losing their importance. Today, given the high marketing investments required, it is essential to develop strategies that best achieve the greatest possible return. This involves studying the relevant tourist markets, understand them and acting according to their needs. The fact that the tourist services are sold at a distance and are paid well in advance before they are consumed by the tourist in the destination increases the importance of promotion, which is partly responsible for the formulation of the destination image and for the trip's motivation. It is therefore essential to study the most important aspects in shaping the image of the destination, so that they may be highlighted in the publicity material. This is because the greater the match between the destination' image created before they visit it, in part, by publicity, and the experience they will enjoy at the destination, the greater will be their satisfaction.

Madeira, which can no longer expect the tourists to hit the door, as happened in the 80's, must invest heavily in advertising. As a matter of fact it must invest an amount that is close to this spent on promotion per available bed by the closest competitors, who bet on the same outbound tourism target markets. But above all, it must adopt effective strategies to guarantee that every euro spent on destination marketing generates the highest possible return, i.e. the largest number of tourist arrivals (or hotel overnights). This may make the big difference in ensuring the success of marketing campaigns in the archipelago. It is also important to examine why Madeira hotels have an average of $25 \%$ of repeated guests every year and to explain 
how the island's image is reinforced after the first visit. This allows establishing a link between image strengthening and tourists' loyalty, which may reduce costs with the destination's promotion.

An analysis of Table 4 allows us to understand the weight of repeat customers in a sample of Madeira hotels. It appears that customer's loyalty does not happen only in the older and more traditional hotels (like the Savoy and Reid's) but also in recent hotels, as well in different categories and types of lodging facilities. For example, the Golden Residence hotel, which has opened in February 2007, already has 2\% of repeat customers after the first year of operation.

Table 4 Repeated guest's statistics in some Madeira hotels

\begin{tabular}{|l|c|c|c|c|c|c|c|}
\hline Unit & Category & $\begin{array}{l}\text { Number } \\
\text { of rooms }\end{array}$ & $\mathbf{2 0 0 5}$ & $\mathbf{2 0 0 6}$ & $\mathbf{2 0 0 7}$ & $\mathbf{2 0 0 8} *$ & $\mathbf{2 0 0 9}$ \\
\hline Hotel Reids & $* * * * *$ & 163 & $40 \%$ & $40 \%$ & $41 \%$ & $41 \%$ & $41 \%$ \\
\hline Hotel Savoy & $* * * * *$ & 337 & $8 \%$ & $10 \%$ & $10 \%$ & $11 \%$ & $12 \%$ \\
\hline Hotel Porto bay & $* * * * *$ & 201 & n.a. & n.a. & $32 \%$ & n.a. & n.a. \\
\hline Hotel Tivoli & $* * * * *$ & 317 & $2 \%$ & $3 \%$ & $3 \%$ & $3 \%$ & $3 \%$ \\
\hline Quinta Jardins do Lago & $* * * * *$ & 41 & $10 \%$ & $11 \%$ & $12 \%$ & $14 \%$ & $16.8 \%$ \\
\hline Hotel Golden Residence & $* * * *$ & 172 & n.a. & n.a. & $1.2 \%$ & $1.8 \%$ & $4.8 \%$ \\
\hline Hotel Girassol & $* * * *$ & 136 & $20 \%$ & $22 \%$ & $24 \%$ & $24 \%$ & $24 \%$ \\
\hline Hotel do Carmo & $* * *$ & 80 & $11 \%$ & $15 \%$ & $15 \%$ & $15 \%$ & $15 \%$ \\
\hline
\end{tabular}

Source: personal survey

* forecast

Given the above mentioned facts the results of this study may be used to improve Madeira's tourism marketing strategies. They will allow the entities that are responsible for regional tourism marketing planning to justify their choices and strategies based on real scientific data.

This paper is divided into eight sections. After a brief introduction in Section 1, Section 2 analyzes the topic and the objectives of the research. Next, Section 3 makes a literature review. Section 4 presents the methodology. Section 5 shows the results of the model. Section 6 presents the conclusions. Section 7 reveals the limitations of the present study. Finally, Section 8 includes recommendations for future research.

\section{Research Topic and Objectives}

As mentioned in the previous section the entry of new tourist destinations in the international tourism market has forced most of them entering a battle to attract more tourists (Konecnick and Gartner, 2006). Small tourism destinations, especially the more isolated island destinations, such as Madeira Island, may be penalized, since there is a concentration of world tourism flows in a relatively small number of countries. To remain competitive in the international tourism market it is vital that 
tourism destinations fully understand the phenomenon of tourism, its players and their reaction behaviour.

The tourist is the key player. So, it is important to study the factors that make him travel to a destination, under both the researchers and the tourism planning and management points of view.

Several international studies show that there are many factors that push tourists to travel, but the destination's image plays a key role. So, it is important to study the following three questions: What image do tourists have of the destination they want to visit? How did they build their imaginary? How can it be influenced, after they visit the destination? How can it influence other tourists to choose the destination?

The analysis and evaluation of tourism destination image is the subject of many studies. From these studies it is known that, in part, destination choice isthe result of the image that the tourists have of the destination and it is dependent on their knowledge, feelings and general opinion about the site. These inputs are processed through cognitive and emotional elements based on information which is transmitted to them by people, by the media and by publicity materials, become reflected in an image. Therefore it is important to know what image tourists have, or they believe that they have, about the destination Madeira, so that its destination marketing can be based on the most relevant aspects, facilitating the communication process. The similarity between the image before visiting the destination and the destination characteristics is a fundamental issue. It can increase the likelihood of positively reinforcing that image, after visiting the destination.

On the other hand, several studies have established a very close relationship between the destination image and satisfaction, because the closer is the previously constructed image of what the experience will be at destination, the greater the satisfaction. And the greater the satisfaction is (and the enhanced destination image after the visit) the greater the likelihood of having repeat customers, or at least of having customers recommending the destination to family members and friends.

However, despite the importance of destination image, there are few, if any, studies on this topic in the Autonomous Region of Madeira. This way, this study contributes to assess some aspects of key importance, such as: the probability that the image of Madeira is improved after the visit; the importance that the enhanced image has on the intention to repeat the visit to Madeira.

\section{Literature review}

Image formation on a specific tourism destination starts when the individual plans the travel and finishes when he/she leaves the destination (Baloglu and McCleary, 1999a, 1999b; Chon, 1990, 1991). Destination image will influence tourists destination choice, the length of stay at the destination, the post trip evaluation and their future choices. Image formation and length of stay are simultaneously defined, 
but while the length of stay is fixed from the beginning, the destination image will change with the destination attributes, the quality of service and so on.

Existing studies have considered the effect of a variety of observed factors on both phenomena. Here, we wish to focus on the influence that unobserved factors may have, once observed factors are controlled for. In order to limit the two types of factors we refer to the portion of destination image determined by observed factors as the expected destination image; deviations from the expected destination image are based in unobserved factors and are referred to as unexpected or unanticipated. If unobserved factors systematically influence both destination image and length of stay, then information about destination image at the end of stay will also reveal information about the length of stay.

An analysis of the studies which has been conducted along the years helps us to understand the stages that the consumer passes by in the process of image shaping. This process starts with the accumulation of destination's images coming from several sources, which changes over time as a result of a long information research process. These images change again during the after purchase and the analysis of the experience's phases.

The purchase of touristic services and their effective consumption is generally separated by time and place. New potential clients don't have any chance to check the product or service attributes before the purchase and because of that they need to have one previous image of the destination. Fayeke and Crompton (1991) argued that because the tourism product is an experience product, which exists only when its consumption starts, promotion plays an even more important role in the construction of a brand image.

Destination image is a very important aspect for the tourism sector since it is a mixture of positive and negative perceptions that represent reality before people choose their travel destination. And only when the positive image exceeds the negative image is that the potential tourists will make their decision of travelling to a certain destination (Milman and Pizan, 1995; Chen and Kerstetter, 1999). So, those destinations associated with stronger positive images have a bigger chance to be considered and chosen (Hunt, 1975; Goodrich, 1978; Pearce, 1982; Woodside and Lysonsky, 1989; Bigné et al., 2001). In addition, the destination image is an important element in the process of tourist's fidelization (Bigné 2001).

Although tourism destinations' image has received a lot of attention in the academic and professional literature in the last few years its concept has not been well defined due to the lack of a solid conceptual framework (Bigné 2001).

According to Gil, Palacio and Beerli (1994), we can identify three different conceptual frameworks to analyse the destination image, namely: (1) from a perceptive and cognitive point of view through the destination attributes values (2) from an affective perspective based on the feelings brought about by the destination (3) from a 
global analysis of the place. And although there is a bigger tendency to define and operate the destination image under a perceptive and cognitive point of view, the more recent studies consider that the image is a concept that is formed through both a rational interpretation (cognitive image) and an emotional interpretation (affective image) of the consumer.

In the context of tourism, Baloglu and McCleary (1999) and Stern and Krakover (1993) show empirically that the perceptive/cognitive evaluations have a direct influence on the general destination image. Some papers published by professionals and academics propose a number of scales to determinate different attributes and measure the tourist's perceived image.

Analysing the main scales we notice some homogeneity concerning the attributes that define individual perceptions (Baloglu and McCleary, 1999a, 1999b; Calantone, Di Benetton, Hakam and Bojanic, 1989; Chon, Weaver and Kim, 1991; Echtner and Ritchie, 1993; Fakeye and Crompton, 1991; Gartner, 1989; Gartner and Hunt, 1987; Gartner and Shen, 1992; Goodrich, 1978; Hu and Ritchie, 1993; Hunt, 1975; Phelps, 1986; Walmsey and Jenkins, 1993). The selection of attributes used to draw a scale, which will depend on the destinations' attractions, its positioning and the perceived image evaluation objectives, will determinate the use of specific or generalized attributes. The destination images formed from organic information sources are those acquired before the experience in the destination, which Phelps (1986) called secondary images. In contrast, primary images are formed through the visit to the destination. The destination choice involves a certain risk and the sources of secondary information play an essential role in the construction of images about the alternative destinations entering the decision process. Although there is a lack of consensus, Mansfeld (1992) showed that secondary sources of information fill three basic functions in the destination choice process: they minimize the decision's associated risk, they create an image of the destination, and later, they justify the choice that was made.

Beerli and Martin (2004) try to prove that the sources of secondary information used by individuals to choose a destination have an important influence in the cognitive dimension. Obviously, the behaviour of those who use external information sources can considerably change, depending on the quantity and types of information sources used. And there are other different sources and types of information which can also contribute in many ways to the image shaping during the "post visit", depending on the importance that the tourist gives to the information sources.

Several authors consider that the primary information acquired from personal experience can be different from the secondary information. In reality, when tourists visit a place their destination image after the visit tends to be more real, complex and different from the one that is formed based in secondary information (Gartner and Hunt, 1987; Pearce, 1982; Phelps, 1986). Fakey and Crompton (1991) emphasize that 
there is a strong consensus among researchers concerning the influence of the visit in the image. Echtner and Ritchie (1993) believe that those who are more acquainted with the destination get more holistic, psicological and unique images, while the less acquainted have images more based on attributes, functional aspects and common characteristics. Several authors show that familiarization, number of visits and the period of stay influence the "perceived image".

One factor related to personal experience is the intensity of the visit, that is, the level of interaction between the individual and the place. According to Sirgy and Su (2000) many studies about the decision process are essentially centred in finding out the answers to the questions related to what, where and how tourists buy, instead of how they buy. Therefore, it is necessary to have more studies about the causes of these choices.

The buying behaviour is particularly relevant in the case of tourism (WoodSide, Caldwell and Abers-Miller, 2004), where a variety of push and pull factors affect the process (Dann, 1977; Decrop, 1999). However, some topics, like selfcongruity, that is the congruency that is created between the tourist's personality and that of the destination, have been ignored in the literature. While in other industries it was empirically tested that self-congruity significantly influences the intention of purchasing, there is still some controversy as far as tourism is concerned. Sirgy and Su (2000) try to clarify the importance that self-congruity has on the choice of the place to visit. Beerli, Menezes and Gil (2004) quote this aspect in their study. This is an empirical study with the purpose of clarifying the role of self-congruity, interpreted as an adaptation between the concept that the tourist has of himself/herself and his/her mental representation of the proposed destination.

After a thorough literature review on this topic, the authors arrived at the same conclusions as Sirgy (1982). In his study he stated that the closest is the destination's image to the concept that the tourist has about himself/herself, the bigger is the tendency of a tourist to visit a place. This study also reveals that the bigger is the travellers' connection to the tourism industry the bigger is the importance of selfcongruity. The conclusions of the mentionedd study are fundamental for destinations that want to capture their potential tourists. Tourist operators, industrial associations and local authorities are becoming more concerned with taking the right decisions as far as promotion is concerned, choosing the ones that are supported by scientific studies.

If one follows the idea that the information, occasionally given to tourists about a destination will be particularly important not only for the promotion of the destination but also in the decision process and that satisfaction will be maximized the closest the destination' image formed in the tourist's mind is to the destination transmited image, then it becomes fundamental to know the tourist and how and why he thinks that way, applying the concept of self-congruity. 
Most of the literature on consumer's behaviour emphasizes the idea that the consumer's satisfaction represents the final step in the psychological process that goes from recognition of needs to the evaluation of experienced products. Oliver (1996) defines the term "satisfaction" as being the consumer's fulfilment in a scale going from very to not very much satisfied, that is, it represents the level of fulfilment of the consumer's expectations relative to a certain destination. The same author (1993) pointed out the difference between general satisfaction with a group of attributes and satisfaction with an individual attribute.

This is a particularly important aspect in hotel services, for example, because the tourist's satisfaction comes from a group of services provided in the several of the hotel departments. However, different levels of satisfaction may exist depending on the service provided.

But, any decline on satisfaction results in a fast decrease of the client's faithfulness. Satisfied and very satisfied clients show different levels of faithfulness. Anderson and Mittal (2000) suggests that satisfaction increases when the firm's performance exceeds consumers' expectations. In the management of tourist destinations, maximizing tourist's satisfaction is an important factor for the destination's success. Satisfaction is associated to the will to return, or to recommend, the destination. The recommendations made by previous tourists (word of mouth) can result in the most important source of information for potential tourists.

For example, Reid's Hotel, one of the first hotels of Madeira and Portugal, having a remarkable history and being a reference in the international hotel industry, and belonging today to one of the most prestigious hotel chains in the world. (Orient Express) has an average of $41 \%$ repeated clients as result of a constant investment on service and guest's satisfaction. However, it is not the only hotel in Madeira adopting that kind of policy. Hotel Savoy, for example, has recently founded a club of repeated clients to which 1700 members have already joined, with the objective to promote fidelization among its guests.

\section{Methodologies}

Research hypotheses

The destination image is of paramount importance to the strategic tourism marketing planning. The study by $\mathrm{Chi}$ and $\mathrm{Qu}$ (2008) suggests the following relationship: Destination Image $\rightarrow$ Satisfaction with the destination attributes $\rightarrow$ Overall satisfaction with the destination $\rightarrow$ Destination loyalty. This functional relationship will be adopted in this study on the analysis of the destination image of Madeira. The destination image strengthening will thus be analyzed based on the satisfaction and loyalty to the destination. The variable used is "Madeira's image strengthening", which is made operational through the following question included in the questionnaire: "Do you think that your image of Madeira has been strengthened 
after your visit?” This variable will be estimated using a Logit model, widely used in research on tourism (Correia, Santos and Barros, 2007).

The following hypotheses $(\mathrm{H})$ are investigated by the model:

H1 (Information): Information is an important determinant of a destination's choice, as, for example, in the case of Madeira. The information gathered by the tourist determines the image of the destination. Information about the destination, obtained through the Net, or through more traditional ways, such as tourist brochures, or advertising institutions, helps the tourist evaluation of the destination, contributing to image shaping (Um and Crompton, 1990; Fodness and Murray, 1997; Bieger and Laesser, 2004).

H2 (Travel motivation): Madeiras's attributes such as the casinos, the nightlife, the weather, or nature, among others, contribute to form Madeira's destination image and to attract tourists (Chi and Quo, 2008). This is a hypothesis widely used in the research on tourist destination's image (Costa and Manente, 1995; Woodside and Lysonski, 1989; Correia, Santos and Barros, 2007).

H3 (Attributes' consumption): The consumption of the destination's attributes carried out by the tourists during their stay, helps defining the destination's image. These attributes can correspond to the characteristics underlying the trip's motivation (or to the image formed before the visit takes place), or to the characteristics offered at the destination (Woodside, Caldwell and Abers-Miller, 2004).

H4 (Expenditures at destination): The expenditure incurred at the destination reflects disposable income available for travelling. Most researchers use the following proxy variables to measure the disposable income available for travelling: prices (De la Vina and Ford, 2001), gross income (Hayand McConnel, 1979; Nicolau and Más, 2005), the travel budget (Correia, Santos and Barros 2007). The present study opts to use the expenditure made at the destination as a proxy variable to measure disposable income for travelling.

H5 (Intention to return to the destination): The image is a central element of tourists' loyalty (Kozak 2001). Thus, the tourist with a good image of Madeira is the one that will most likely be willing to return. The tourist's evaluation of his experiences in Madeira influences, modifies and can reinforce the image of Madeira and hence the intention to return. 
H6 (Quality): The destination overall quality, evaluated by the tourist, is a key element in enhancing the image of the destination. A tourist that evaluates Madeira as a tourism destination offering a global experience with a high overall quality, will ultimately enhance his image of Madeira (Chi and Qu, 2008)

H7 (Satisfaction): The tourist's satisfaction with the destination helps to strengthen the image of the destination (Chi and Qu, 2008). Thus, the satisfaction of tourists who visited Madeira reinforces their image of that destination.

The model

This study uses a Logit model to examine the probability that their image of Madeira can be enhanced after the visit to the destination, with the following properties:

a) $y_{i}=1$, if the tourist's image of Madeira has been strengthened after a trip to Madeira;

b) $y_{i}=0$, if the tourist's image of Madeira has not been strengthened after a trip to Madeira;

The above mentioned variable is explained by Madeira destination's characteristics (attributes), represented by a vector $\mathrm{x}_{\mathrm{i}}$, so that the probability that the image is strengthened is defined by: $P\left(y_{i}=1 \mid x_{i}\right)$.

When $\varepsilon_{i}$ is an independent and identically distributed error term, with a type I extreme value, we can obtain the probability that the image is strengthened, by estimating the popular Logit model, described by the following equation, (Ben-Akiva and Lerman, 1985): Hilbe, Joseph M. (2009).

$$
P\left(y_{i}=1 \mid x_{i}\right)=P\left(\beta, x_{i}\right)=\frac{e^{\beta^{\prime} x_{i}}}{1+e^{\beta^{\prime} x_{i}}}
$$

Ben-Akiva and Lerman (1985) and Train (1993) used the Logit model to relate the probability of making a choice with a set of variables that reflect the preferences of the person who makes the choice.

\section{Working tools}

The main working tool used was a survey of tourists visiting Madeira during the months of April, May, June and July 2008. The survey involved the following steps: 
1. Design of the questionnaire. The questionnaire's design was based on the literature review;

2. Definition of the variables to be included in the questionnaire, their type and measurement scale;

3. The collection of the questionnaires;

4. Coding the variables used in the questionnaire, in order to perform the statistical analysis;

5. Creating a database, using the Excel software program;

6. Defining the criteria used to perform the quality control of the data and to detect input errors. This contributes to a greater reliability of the collected information and a greater confidence in the results obtained;

7. Implementation of the data base control;

8. Choice of the statistical methods to apply, taking into account the objectives outlined for the study. Initially, these statistical methods consist of a descriptive analysis of the data, including descriptive measures (means, medians, minimum, maximum, and standard deviation), frequencies (absolute, relative), tables and graphs. In a second phase, the statistical inference methods are chosen, including the testing of hypotheses, to derive the conclusions for the population of the study. Multivariate analysis is also performed, more specifically, categorization and principal components analysis, to identify market segments (groups);

9. Statistical analysis.

The survey and the data

In order to test the seven hypotheses listed above the questionnaire was implemented and the respondents were a random sample of foreign tourists in the departure lounge of Madeira's airport. During the months of April, May, June and July 2008 , a total of 550 tourist surveys were implemented. The level of response was $80 \%$ and 353 surveys were validated.

Surveys to ten directors of various categories and types of accommodation units in Madeira were also implemented. In addition, more in-depth interviews were held to the directors of a five star inn (the "Lake Gardens"), a traditional five-star hotel (Hotel Savoy) and a recent four-star hotel (the"Golden Age Residence").

The accommodation units sample includes ten lodging units, all located in Funchal, namely: a 5-star inn (Quinta), three 5-star hotels, three 4-star hotels, two 3stars hotels and a 3-stars pension (residential).

The sample, collected in Funchal airport, revealed that $53 \%$ of respondents were men and $47 \%$ women, with an average age of 33 years. Among them, $78 \%$ have secondary education and 33\% have higher education and belong, in general, to the middle class with a one child family. The population under study was defined as the 
number of monthly tourists leaving Madeira by the Funchal airport. Based in the population, a representative sample survey was set up, which appears in Table 5.

Table 5 Characteristics of the population under study - Madeira Airport departures in the first seven months of 2008

\begin{tabular}{|l|l|l|l|l|}
\hline $\mathbf{2 0 0 8}$ & $\begin{array}{l}\text { Total } \\
\text { passengers }\end{array}$ & $\begin{array}{l}\text { Total } \\
\text { departures }\end{array}$ & $\begin{array}{l}\text { Number of } \\
\text { tourists }\end{array}$ & Sample \\
\hline January & 173360 & 100313 & 51958 & \\
\hline February & 168966 & 83358 & 53300 & \\
\hline March & 234398 & 117124 & 73912 & \\
\hline April & 216503 & 108467 & 67284 & \\
\hline May & 219392 & 110129 & 60816 & 179 \\
\hline June & 207119 & 103044 & 58968 & 158 \\
\hline July & 220947 & 104800 & 56196 & 161 \\
\hline
\end{tabular}

Source: “Madeira Airports and Air Transport”, Annual Bulletin, 2008

In 2007 there were a total of 2408250 passengers in Funchal airport, corresponding to 1205274 departures and the total tourist departures were 678655 . The sample was obtained using the confidence interval method (Burns and Busch, 1995). The formula used to estimate the sample size with a $95 \%$ significance level is as follows:

$$
n=\frac{z^{2}(p q)}{e^{2}}=\frac{1.95^{2}(0.5 \times 0.5)}{0.05^{2}}=385
$$

Where: $z$ is the standard error associated with the chosen significance level (95\%); $p$ is the estimated variation in the population (50\%); $q=1-p$ (50\%); $e$ is the $5 \%$ samples' error term. The level of variation in the population is unknown, and it was set at $50 \%$, since this is the level currently adopted in the social science research.

The procedure followed consisted of an interviewer who presented the questionnaire to the tourists in the Funchal airport's departure lounge, before their boarding. Considering the sample size, the time available and the budget constraints, the maximum number of questionnaires was set at 550, assuming a non-response rate of $30 \%(385 /(1-0.3)=550)$. The number of questionnaires obtained was 498 , but only 346 completed questionnaires were retained for the analysis in this study. The remaining questionnaires were not considered valid, because they were incomplete or incorrectly filled. The response rate did not vary significantly in terms of nationality, age or gender of the population. The characteristics of the variables used in the model are presented in Table 6 . 
Table 6 Variables description

\begin{tabular}{|c|c|c|c|c|c|}
\hline Variables & Description & Min & Max & Mean & $\begin{array}{l}\text { Standard } \\
\text { deviation }\end{array}$ \\
\hline $\begin{array}{l}\text { Dependent } \\
\text { variable: } \\
\text { Madeira's image } \\
\text { strengthening }\end{array}$ & $\begin{array}{l}\text { Dummy variable: Do you think that your image of } \\
\text { Madeira has been strengthened after your visit? }\end{array}$ & 0 & 1 & 0.312 & 0.464 \\
\hline $\begin{array}{l}\text { Independent } \\
\text { variables }\end{array}$ & Hypothesis 1: Information & & & & \\
\hline \multirow[t]{2}{*}{ Internet } & $\begin{array}{l}\text { How important was internet in your decision? (1-not } \\
\text { important, 5-very important) }\end{array}$ & 1 & 5 & 3.673 & 1.066 \\
\hline & Hypothesis 2: Trip Motivation & & & & \\
\hline $\begin{array}{l}\text { Fado (Portuguese } \\
\text { national song) }\end{array}$ & $\begin{array}{l}\text { Why did you choose Madeira?: Fado (1-not important, } \\
\text { 5-very important) }\end{array}$ & 1 & 5 & 3.315 & 1.060 \\
\hline Handicrafts & $\begin{array}{l}\text { Why did you choose Madeira?: Handicrafts (1-not } \\
\text { important, 5-very important) }\end{array}$ & 1 & 5 & 3.779 & 0.812 \\
\hline Casinos & $\begin{array}{l}\text { Why did you choose Madeira?: Casinos (1-not } \\
\text { important, 5-very important) }\end{array}$ & 1 & 5 & 3.142 & 1.153 \\
\hline \multirow[t]{2}{*}{ Health } & Why did you choose Madeira? - Health (Yes=1, No=0). & 0 & 1 & 0.309 & 0.462 \\
\hline & Hypothesis 3. Consumption at the Destination & & & & \\
\hline Fado1 & Did you attend any Fado live show? $(\mathrm{Yes}=1, \mathrm{No}=0)$ & 0 & 1 & 0.069 & 0.254 \\
\hline Wine & Did you buy wine? $(\mathrm{Yes}=1, \mathrm{No}=0)$ & 0 & 1 & 0.404 & 0.491 \\
\hline Shopping & Did you go shopping? $(\mathrm{Yes}=1, \mathrm{No}=0)$ & 0 & 1 & 0.141 & 0.349 \\
\hline Tours & Did you buy any organized tours? (Yes=1, No=0) & 0 & 1 & & \\
\hline Tours 1 & Did you engage in any free tours? ( $\mathrm{Yes}=1, \mathrm{No}=0$ ) & 0 & 1 & 0.349 & 0.477 \\
\hline \multirow[t]{2}{*}{ Night Life } & Did you enjoy night life? (Yes=1, No=0) & 0 & 1 & 0.384 & 0.487 \\
\hline & Hypothesis 4: Expenditures at the Destination & & & & \\
\hline \multirow[t]{2}{*}{$\begin{array}{l}\text { Variation in the } \\
\text { expenditure at the } \\
\text { destination }\end{array}$} & $\begin{array}{l}\text { Did you spent more after your first visit to Madeira? } \\
\text { Yes=1, Don't know=2, No=0. }\end{array}$ & 0 & 2 & 0.400 & 0.541 \\
\hline & Hypothesis 5:Visit's repetition & & & & \\
\hline \multirow[t]{2}{*}{$\begin{array}{l}\text { Repeated visits } \\
\text { intention }\end{array}$} & $\begin{array}{l}\text { Do you intend to return to Madeira? (Yes=1, Don't } \\
\text { know=2, } \mathrm{No}=3 \text { ) }\end{array}$ & 1 & 3 & 1.457 & 1.261 \\
\hline & Hypothesis 6: Quality & & & & \\
\hline \multirow[t]{2}{*}{$\begin{array}{l}\text { Destination } \\
\text { Services Quality }\end{array}$} & Did you like the service’s quality? (1-low, 5-very high) & 1 & 5 & 4.104 & 0.703 \\
\hline & Hypothesis 7: Satisfaction & & & & \\
\hline Satisfaction & What is your satisfactions' level? (1-low, 5-very high) & 1 & 5 & 4.205 & 0.512 \\
\hline
\end{tabular}

\section{Results}

Table 7 presents the variables and the statistical significance of the estimated model. The standard Logit model, together with the marginal effects for continuous variables, and partial effects for dichotomous variables, was estimated with the Stata software. 
Table 7 Estimates of the parameters and the $Z$ statistic.

\begin{tabular}{|c|c|c|c|c|}
\hline & \multicolumn{2}{|c|}{ Logit Model } & \multicolumn{2}{|c|}{ Marginal effects } \\
\hline Variables & Coefficients & Statistic $-\mathrm{z}$ & Coefficients & Statistic -2 \\
\hline Constant & -7.043 & -3.75 & - & - \\
\hline \multicolumn{5}{|l|}{ Information } \\
\hline Internet & -0.433 & -2.66 & -0.067 & -2.66 \\
\hline \multicolumn{5}{|l|}{ Trip Motivation } \\
\hline "Fado" & -0.608 & -2.90 & -0.094 & -2.98 \\
\hline Handicrafts & -0.371 & -1.76 & -0.057 & -1.76 \\
\hline Casinos & 0.355 & 1.94 & 0.055 & 1.9 \\
\hline Health & 0.942 & 2.50 & 0.162 & 2.32 \\
\hline \multicolumn{5}{|l|}{ Consumption at the Destination } \\
\hline "Fado1”" & 1.881 & 2.88 & 0.405 & 2.65 \\
\hline Wine & 1.231 & 3.60 & 0.204 & 3.50 \\
\hline Shopping & 1.036 & 2.27 & 0.197 & 1.97 \\
\hline Tours & 0.800 & 2.06 & 0.131 & 1.99 \\
\hline Tours (1) & 1.340 & 3.45 & 0.233 & 3.22 \\
\hline Night Life & 1.312 & 2.17 & 0.268 & 1.87 \\
\hline \multicolumn{5}{|l|}{ Expenditures at the Destination } \\
\hline Variation in the expenditure at the destination & 0.645 & 2.03 & 0.100 & 2.05 \\
\hline \multicolumn{5}{|l|}{ Visit repetition } \\
\hline Repeated visit intention & 0.551 & 3.79 & 0.085 & 3.80 \\
\hline \multicolumn{5}{|l|}{ Quality } \\
\hline Destination Services Quality & 0.851 & 3.06 & 0.132 & 3.12 \\
\hline \multicolumn{5}{|l|}{ Satisfaction } \\
\hline Satisfaction & 0.713 & 2.16 & 0.111 & 2.1 \\
\hline \multicolumn{5}{|l|}{ Model's Statistics } \\
\hline $\operatorname{LR~chi~}^{2}(15)$ & 165.92 & & & \\
\hline Log likelihood & -124.847 & & & \\
\hline Pseudo $\mathrm{R}^{2}$ & 0.3992 & & & \\
\hline Pearson chi $^{2}(313)$ & 363.94 & & & \\
\hline
\end{tabular}

Note: Dependent variable: Do you think that your image of Madeira has been strengthened after your visit? $($ Yes $=1$, No $=0)$

The models' $\beta$ parameters relate variations in the explanatory variables $X_{i}$ with variations in the probability of enhancing the image of the destination. While the sign of the parameters indicates the direction of the relationship, their values are not directly interpreted as marginal variations. To estimate the amount of variation occurred one calculates the estimated marginal effects, which in the case of dichotomous variables correspond to the partial effects. One can therefore say, based on the results that the existence of a casino in Madeira generates a variation of $5.5 \%$ in the probability of considering that the image of Madeira is valued after the trip. The model fits the data appropriately and the LR statistic rejects the hypothesis that the parameters are generally equal to zero, for a significance level of $1 \%$. The asymptotic 
values of the $\mathrm{z}$ statistics measure the statistical significance of the model. The results show that the variables that contribute most to enhancing the image of Madeira are: the intention to return to the destination, wine, free tours and destination services quality. This means that these are the most important variables to take into consideration when defining a policy aimed at improving Madeira's destination image. The results obtained also show that: The information obtained from the Internet contributes negatively to the destination image; the attributes of the destination, the "fado" and handicrafts travel motivations also exhibit a negative contribution to strengthening the image of the destination, but in the first case, the consumption of "fado" changes that result; the casino and health are both motivations that contribute positively to the enhanced image; the consumption of goods in the destination contributes considerably to the strengthening of the image; the variation in the expenditures at the destination, the repeated visit intention, the destination services quality and the satisfaction are all contributing to strengthening the image of the destination.

The model's results have the following meanings:

1) The image of Madeira is improved after the visit to the island, being reinforced by the tourists' loyalty. Their loyalty is revealed through the intention to return to the destination and it is a key element to the management of hotels in Madeira. In this regard, the Director of Reids Hotel, one of the most prestigious hotels in the world said, during our interview, that the secret of having a rate of $41 \%$ of repeat customers lies in just one point: Treat them well! Take very good care of them! Therefore we see that there isn't a properly structured strategy to capture those customers. This is contrary to what is currently done abroad, especially in hotel chains located in many cities, where there is a growing competition between units, forcing them to develop appropriate loyalty programmes and initiatives. Since there is a general view that the customer's loyalty is of paramount importance to strengthening the destination's image and to increase occupancy rates and revenue per customer, it would be recommendable that the hotels in Madeira establish a strategic planning targeting the segment of repeated clients, with the aim of further increasing the rate of repeated visits. Perhaps this would be a way to offset the drop in occupancy rates in Madeira hotels, which has been taking place in the last decade. The loyalty programs, for example, adapted from other branches of tourism activity, such as airlines and renta-car, are reaching the hotel sector, in order to retain customers.

2) The Madeira Wine tours and the tours on your own (not organized) are two of the attributes that contribute most to satisfaction with the destination. This means that the image of tourism in the destination is still associated with Madeira winemaking traditions and the freedom to "explore" the island (not through organized tours). Therefore the importance of these traditional attributes which in the last century formed Madeira tourism destination image remains the same. 
3) The quality of services at the destination is important for enhancing the image of Madeira. For example, the Reids Hotel, a landmark in the history of international hotels, which now belongs to one of the most prestigious hotel chains in the world, has, on average, $41 \%$ of repeat customers. This is the result of a permanent stake in the excellence of service and customer satisfaction. The Hotel Savoy also has the objective of delivering a quality service and therefore it has founded, recently, a club of repeat customers, which has now 1700 members. The directors of these hotels mentioned, in the interviews, that the reasons that lead customers to return are the attention, the sympathy and the good services provided, which exceed their expectations. These policies are the outcome of normal procedures in many Madeira hotels with high quality standards.

4) There are other factors, equally important to the destination's image, such as the satisfaction obtained during the trip. The tourist's satisfaction is a tool used to assess the visit's experience. Positive experiences at the level of service, or any other characteristic offered by a tourist destination, can produce an enhanced image of the destination, repeat visitors and a positive effect on the destination word-of-mouth publicity, which is very important to attract potential visitors, acquaintances, friends or relatives. Overall, the study shows that, although there are many variables included in the questionnaires, few are really important. The most important indeed are those associated with the traditional attributes of Madeira tourism destination, suggesting that the image of Madeira, in general, remains that of a traditional tourist destination.

\section{Conclusions}

The results of studies on the destination image, such as Chi and Qu (2008) and Nadeau et al. (2007), confirm those obtained in the present research. This study uses a parsimonious model to evaluate the importance of satisfaction, quality and intention to return, to strengthen the image of Madeira tourism destination. But it also identifies other relevant attributes, specific to Madeira. However, the studies by Chi and Qu (2008) and Nadeau et al.(2007) used a structural variables model, whereas we have opted here for the Logit model. It is therefore not possible to make a detailed comparison between these studies.

One important finding is that the main factors that define the image of Madeira are traditional factors, which have been in action for years. Therefore it is necessary that the Department of Transport and Tourism of Madeiras's Regional Government adopt pro-active policies to change the image of the destination, defining strategies to provide more attention to alternative tourism products, such as a modern craft, and cultural events to enhance the nightlife.

Finally, it is expected that this study may in some way stimulate tourism authorities and entrepreneurs to provide data that may serve as the basis for future research in the field of destination image and to allow all stakeholders to benefit from 
the findings of the above mentioned results, using them to define and implement future development strategies, based on an enhanced image of Madeira tourism destination.

This study has some limitations. Firstly the sample size is relatively small. Therefore, it is difficult to make good statistical inferences. Some variables are not significant simply because the sample is too small. It would be useful to check the statisc significance of the variables related with the tourist's profile (nationality, sex, age, etc.) with a larger sample. Secondly, the generalization for the whole year of the results obtained is highly debatable. It would be good to implement the questionnaire during a longer period of time, not just the months of May, June and July. Finally, the number of English tourists in the sample is greater than their representation in the population of tourists who visit Madeira in the sample's months, which probably introduces a bias in the results. This over-representation of English tourists is due to two factors: first, the questionnaire was implemented only to passengers travelling in low-cost carriers, which have recently started to operate between Madeira and the United Kingdom, and secondly, the questionnaire was administered only in English.

There is, as we saw in the literature review, a wide range of studies of destination image. Following this study and in order to improve its limitations, it is proposed to conduct the following research:

a) Use the database to analyze the duration of stay in Madeira of repeat tourists, using other models, such as the survival model;

b) Test the rate of return to Madeira destination, using a Order Probit Models, which allows to take into account both the heterogeneity (different characteristics of the tourists), and the endogeneity (the explanatory variables being correlated with the dependent variable);

c) Implement the questionnaire in the other months of the year, thus capturing different segments of tourists who visit Madeira.

\section{References}

1. Anderson E.W., Mittal V. (2000) Strengthening the satisfaction profit chain. Journal of Service Research, 3(2), pp.107-120

2. Baloglu, S, and K. W. McClearly (1999a) A model of destination image formation. Annals of Tourism Research, 26(4), pp. 868-897.

3. Baloglu, S, and K. W. McClearly (1999b) U.S. international pleasure travelers' images of four mediterranean destinations: A comparasion of visitors and nonvisitors. Journal of Travel Research, 38(2), pp. 114-129

4. Baloglu, S. (2001). An investigation of a loyalty typology and the multidestination loyalty of international travellers. Tourism Analysis, 6(1), pp. 41-52.

5. Beerli, A., J. Martín (2004) Factors influencing destination image. Annals of Tourism Research, 31(3), pp. 657-681. 
6. Beerli, A., and Martín, J. D. (2004) Tourists' characteristics and the perceived image of tourist destinations: a quantitative analysis - a case study of Lanzarote, Spain. Tourism Management, 25 (5), pp. 623-636.

7. Beerli Asunción, Meneses, G. D. and Gil, S. M. (2004) Self congruity and destination choice. Annals of Tourism Research, 34(3), pp. 571-587.

8. Ben-Akiva M., Lerman S. (1985) Discrete choice analysis. Cambridge, Massachusets: MIT Press.

9. Train, K. E. (1993) Qualitative choice analysis: Theory econometrics, and an application to automobile demand. Cambridge, Massachusets: MIT Press.

10. Bieger, T. and C. Laesser (2004) Information sources for travel decisions: Towards a source process model. Journal of Travel Research, 42(4), pp. 357-371.

11. Bigné, J. and L. Andreu (2004) Emotions in segmentation: an empirical study. Annals of Tourism Research, 31(3), pp. 682-696.

12. Calantone, R., C. di Benetton, A. Hakam and D.Bojanic (1989) Multiple Multinational tourism positioning using correspondence analysis. Journal of Travel Research, 28(1), pp. 25-32

13. Chen, P. and D. Kerstetter (1999) International students' image of rural Pennsylvania as a travel destination. Journal of Travel Research, 37(3), pp. 256-266.

14. Chi, C. G. Q. and H. Qu (2008) Examining the structural relationship of destination image, tourist satisfaction and destination loyalty: An integrated approach. Tourism Management, 29(4), pp. 624-636.

15. Chon, K. (1990) The role of destination image in tourism: A review and discussion. The Tourist Review, 45(2), pp. 2-9.

16. Chon, K. (1991) Tourism destination image modification process. Tourism Management, 12(1), pp. 68-72.

17. Chon, K., P. Weaver and C. Kim (1991) Marketing your community: Image analysis in Norfolk. Cornell Hotel and Restaurant Administration Quarterly 31(4), pp. 31-37.

18. Correia, A., C. M. Santos, and Barros, C. P. (2007) Tourism in Latin America: A choice analysis. Annals of Tourism Research, 34(3), pp. 610-629.

19. Costa, P. and M. Manente (1995) Venice and its visitors: A survey and a model of qualitative choice. Journal of Travel and Tourism Marketing, 4(3), pp. 45-69.

20. Dann, M. (1977) Anomie, ego-enhancement and tourism. Annals of Tourism Research, 4(4), pp. 184-194.

21. Decrop. A., (1999) Personal aspects of vacationer's decision making process: An interpretive approach. Journal of Travel and Tourism Marketing, 8(4), pp. 59-68.

22. de la Vina, L. and J. Ford (2001) Logistic regression analysis of cruise vacation market potential: Demographic and trip attribute perception factors. Journal of Travel Research, 39(4), pp. 406-410. 
23. Echtner, C. M. and J. R. B. Ritchie (1993) The measurement of destination image: An empirical assessment. Journal of Travel Research, 31(4), pp. 3-13.

24. Fakeye, P. C. and J. L. Crompton (1991) Image differences between prospective, first time and repeat visitors to the Lower Rio Grande Valley. Journal of Travel Research, 30(2), pp. 10-16.

25. Fodness, D. and B. Murray (1997) Tourist information search. Annals of Tourism Research, 24(3), pp. 503-523.

26. Gartner, W. C. (1986) Temporal influences on images change. Annals of Tourism Research, 13(4), pp. 635-644.

27. Gartner, W. C. (1989) Tourism image: Attribute measurement of state tourism products using multidimensional scaling techniques. Journal of Travel Research, 28(2), pp. 16-20.

28. Gartner, W., and J. Hunt (1987) An analysis of state image change over a twelve-year period (1971-1983). Journal of Travel Research, 26(1), pp. 15-19.

29. Gartner, W. and J. Shen (1992) The impact of Tiananmen Square on China's tourism image. Journal of Travel Research, 30(4), pp. 47-52.

30. Gil, S. M., Beerli, A. P., and Martin, J. D. (2004) La conception sistemática de la imagen del destino: Una aproximación desde la imagen del alojamiento. Punta Delgada, Portugal: Universidade de Las Palmas.

31. Goodrich, J. (1978) A new approach to image analysis through multidimensional scaling. Journal of Travel Research, 16(3), pp. 3-7.

32. Hay, M. and K. McConnel (1979) An analysis of participation in nonconsumptive wildlife recreation. Land Economics, 55(4), 460-471.

33. Hilbe, J. M. (2009). Logistic Regression Models. Chapman and Hall/CRC Press.

34. Hunt, J. D. (1975) Image as a factor in tourism development. Journal of Travel Research, 13(4), pp. 1-7.

35. Hu, Y., and J. R. B. Ritchie (1993) Measuring destination attractiveness: A contextual approach. Journal of Travel Research, 32(2), pp. 25-34.

36. Konecnick, M. and C. W. Gartner (2007) Customer-based brand equity for a destination. Annals of Tourism Research, 34(2), pp. 400-421.

37. Kozak, M. (2001) Repeaters' behavior at two distinct destinations. Annals of Tourism Research, 28(3), pp. 784-807.

38. Kuusik, A. (2007) Affecting customer loyalty: Do different factors have various influences in different loyalty levels? University of Tartu, Faculty of Economics and Business Administration Working Paper 58. URL: http://infutik.mtk.ut.ee/www/kodu/RePEc/mtk/febpdf/febawb58.pdf (Accessed on 04.05.2009)

39. Lee, K. C.g, K.-Y. Lee and KooBong Lee (2005) Korea's destination image formed by the 2002 World Cup. Annals of Tourism Research, 32(4), pp.839-858. 
40. Mansfeld, Y. (1992) From motivation to actual travel. Annals of Tourism Research, 19(3), pp. 399-419.

41. Milman, A. and A. Pizam (1995) The role of awareness and familiarity with a destination: The Central Florida case. Journal of Travel Research, 33(3), pp. 21-27.

42. Nadeau, J., L. Heslop, N. O’Reilly and P. Luk (2007) Destination in a country image context. Annals of Tourism Research, 35(1), pp. 84-106.

43. Nicolau J. and F. Más (2005). Stochastic modelling: a three-stage tourist choice process. Annals of Tourism Research, 32(1), pp.49-69.

44. Oliver, R. L. (1996) Satisfaction: a behavioral perspective on the consumer. Boston: McGraw -Hill Company.

45. Pearce, P. (1982) Perceived changes in holiday destinations. Annals of Tourism Research, 9(2), pp. 45-164.

46. Phelps, A. (1986) Holiday destination image - the problem of assessment. Tourism Management, 7(3), pp. 168-180

47. Sirgy, M. J. and C. Su (2000) Destination image, self congruity, and travel behavior: Towards an integrative model. Journal of Travel Research, 38(4), pp. 340352.

48. Sirgy, M. J. (1982) Self-concept in consumer behavior: A critical review. Journal of Consumer Research, 9(3), pp. 287-300

49. Stern, E. and S. Krakover (1993) The formation of a composite urban image. Geographical Analysis, 25(2), pp. 130-146.

50. Um, S. and J. Crompton (1990) Attitude determinants in tourism destination choice. Annals of Tourism Research, 17(3), pp. 432-448.

51. Walmsey, D. J. and J. M. Jenkins (1993) Appraisive images of tourist areas: Application of personal constructs. Australian Geographer, 24(2), pp. 1-13.

52. Woodside, A. and S. Lysonsky (1989) A general model of traveler destination choice. Journal of Travel Research, 27(4), pp. 8-14.

53. Woodside, A., N. Caldwell and D. Albers-Miller (2004) Broadening the study of tourism: Introduction to the Special Issue on the Consumer psychology of travel/tourism behavior. Journal of Travel and Tourism Marketing, 17(1), pp. 1-6.

54. Woodside, A. G. and R. MacDonald (1994) General system framework of customer choice processes of tourism services. In R. Gasser, K. Weiermair (Eds) Spoilt for choice: decison making processes and preference changes of tourists: intertemporal and intercountry perspectives. Proceedings of the International Conference at the University of Innsbruck, November, 1993. Thaur, Austria: Kulturverlag, pp. 30-59.

RECEIVED: 14.11.2008

ACCEPTED: 20.04.2009 